\title{
Capsule per Animal
}

National Cancer Institute

\section{Source}

National Cancer Institute. Capsule per Animal. NCI Thesaurus. Code C74918.

A dose calculation unit expressed in capsule(s) per animal. 